\title{
Efektivitas Penggunaan Software Pembelajaran Daring Dimasa Pandemi Covid-19 pada Guru SD Negeri 2 Abiansemal
}

\author{
I Gusti Ayu Agung Sinta Diarini' ${ }^{1}$ I Made Ari Winangun ${ }^{2}$ \\ ${ }^{1}$ Universitas Dhyana Pura \\ ${ }^{2}$ STAHN Mpu Kuturan Singaraja \\ ${ }^{1}$ gungsinta@undhirabali.ac.id
}

\begin{abstract}
Most of the teachers at SD Negeri 2 Abiansemal have not been able to carry out online learning to the fullest during the Covid-19 pandemic. This causes the learning process to run monotonously. Therefore, efforts are needed to maximize the ability of teachers to use online learning software. This effort was carried out in the form of research that aims to analyze the effectiveness of using online learning software during the Covid19 pandemic for teachers at SD Negeri 2 Abiansemal. This research is a pre-experimental design with a one-group pretest-posttest design model. The population and sample of this study were all 16 teachers at SD Negeri 2 Abiansemal. The instrument used is the SAMR model test. Data analysis in this study was paired t-test as a difference test and $N$-gain as an effectiveness test. The results of this study indicate that the use of online learning software during the Covid-19 pandemic for teachers at SD Negeri 2 Abiansemal is effective in improving teaching abilities. (pretest $<$ posttest $=64.06<92.19 ; t_{\text {count }}>t_{\text {table }}$ $=25,422>2,131 ;$ sig. $(2$-tailed $)<\alpha ; N$-gain $=79,98 \%)$.
\end{abstract}

Keywords: Effectiveness; Online Learning Software; Elementary School Teacher

\begin{abstract}
Abstrak
Sebagian besar guru di SD Negeri 2 Abiansemal belum mampu melaksanakan pembelajaran daring dimasa pandemi Covid-19 dengan maksimal. Ini menyebabkan proses pembelajaran berjalan dengan monoton. Oleh karena itu diperlukan upaya untuk memaksimalkan kemampuan guru dalam menggunakan software pembelajaran daring. Upaya ini dilakukan dalam bentuk penelitian yang bertujuan untuk menganalisis efektivitas penggunaan software pembelajaran daring dimasa pandemi Covid-19 pada guru SD Negeri 2 Abiansemal. Penelitian ini merupakan pre-experimental design dengan model one-group pretest-posttest design. Populasi dan sampel penelitian ini merupakan seluruh guru di SD Negeri 2 Abiansemal yang berjumlah 16 orang. Instrumen yang digunakan adalah tes model SAMR. Analisis data dalam penelitian ini adalah uji-t berpasangan sebagai uji beda dan $\mathrm{N}$-gain sebagai uji efektivitas. Hasil penelitian ini menunjukkan bahwa penggunaan software pembelajaran daring dimasa pandemi Covid19 pada guru SD Negeri 2 Abiansemal efektif meningkatkan kemampuan mengajar. (pretest $<$ posttest $=64,06<92,19 ; \mathrm{t}_{\text {hitung }}>\mathrm{t}_{\text {tabel }}=25,422>2,131 ;$ sig. $(2$-tailed $)<\alpha ; \mathrm{N}$ gain $=79,98 \%)$.
\end{abstract}

Kata Kunci: Efektivitas; Software Pembelajaran Daring; Guru SD

\section{Pendahuluan}

Masyarakat dunia saat ini sedang dihadapkan pada pandemi Covid-19 yang menyerang saluran pernapasan. Wabah tersebut telah menjangkiti ratusan ribu penduduk di Indonesia dan bahkan ribuan diantaranya meninggal dunia. Hal ini mempengaruhi 
segala sektor kehidupan manusia salah satunya pendidikan. Budaya belajar yang awalnya berlangsung secara tatap muka berubah dengan sistem pembelajaran online atau proses belajar dari rumah sesuai dengan Surat Edaran Mendikbud Nomor 4 Tahun 2020. Keadaan ini mempengaruhi kinerja guru sebab diperlukan adaptasi yang cepat dalam menguasai teknologi.

Perubahan budaya belajar dan dampaknya tersebut juga dialami oleh guru di SD Negeri 2 Abiansemal. Berdasarkan analisis situasi yang telah dilakukan, guru belum terbiasa mengajar dengan memanfaatkan media daring yang kompleks, mudah diakses, dan dipahami siswa. Pada sisi lain siswa membutuhkan budaya belajar yang baru. Situasi ini menyebabkan proses pembelajaran kurang up date, kurang menarik, dan cenderung monoton sehingga berdampak pada kualitas pembelajaran yang rendah. Padahal proses pembelajaran daring dimasa pandemi Covid-19 menjadi sebuah keharusan sehingga diperlukan penguasaan aplikasi penunjang pembelajaran daring.

Situasi ini semakin memprihatinkan karena ketersediaan sarana prasarana pendukung pembelajaran daring di SD Negeri 2 Abiansemal masih minim. Sekolah hanya memiliki fasilitas laptop atau komputer 3 buah saja yang masih layak digunakan untuk mengajar di enam tingkat. Keadaan ini membuat rendahnya motivasi guru untuk menggunakan laptop sebagai sarana pembelajaran yang inovatif. Guru lebih banyak menggunakan smart phone untuk melakukan pembelajaran melalui WhatsApp Group yang dalam implementasinya belum maksimal. Banyak siswa hanya sekedar mengirim foto saat belajar untuk sekedar menunjukkan kehadiran mereka. Proses pembelajaran tidak maksimal, ada beberapa orang tua yang membuatkan tugas anaknya sedangkan siswa sendiri sibuk bermain dengan temannya tanpa melakukan proses pembelajaran dengan baik. Begitu pua, proses belajar yang monoton setiap hari membuat para siswa mengabaikan proses belajarnya yang tidak menarik dan memilih kegiatan yang memberikan tantangan baru dalam kegiatan permainan.

Upaya yang dilaksanakan dalam mengatasi permasalahan ini, yaitu dengan melaksanakan pembelajaran daring dan pendampingan model SAMR sebagai alat bantu pembelajaran. Upaya-upaya ini diharapkan memberikan pengetahuan dan pemahaman kepada guru tentang jenis-jenis pembelajaran online sehingga mampu membuat media pembelajaran, membuat video tutorial, mengunduh materi pembelajaran, dan mengevaluasi pembelajaran sehingga mewujudkan pembelajaran yang inovatif sesuai dengan tuntutan zaman. Selain itu, pembelajaran daring dengan SAMR juga diharapkan mampu memaksimalkan perangkat yang dimiliki sekolah dan para guru baik itu smart phone ataupun laptop sebagai sarana atau media teknologi pembelajaran untuk mewujudkan pembelajaran dari yang berkualitas.

Secara empiris, pembelajaran daring dengan google classroom mampu mempermudah akses kebutuhan belajar dan meningkatkan hasil belajar (Rahmanto \& Bunyamin, 2020; Baety \& Munandar, 2021). Begitu pula, pembelajaran daring melalui zoom meeting dapat meningkatkan hasil belajar (Novita et al, 2021), fleksibel dan menarik (Monica \& Fitriawati, 2020), serta mampu mewujudkan interaktivitas secara real time (Joia \& Lorenzo, 2021). Kedua jenis software pembelajaran daring tersebut dan beberapa software lainnya dapat dikelompokkan menjadi platform video konferensi yaitu zoom, webex, dan MS team, serta sistem pengelolaan pembelajaran berupa moodle, blackboard, dan google classroom (Dias et al, 2020). Kedua kelompok besar jenis software ini jika dikolaborasikan dapat memberikan alternatif pembelajaran daring yang tepat dimasa pandemi Covid-19.

Dilihat dari aspek kompetensi peserta didik ataupun pengguna lainnya, penggunaan software pembelajaran daring dapat meningkatkan hasil belajar (Rahmanto, 2020; Baety \& Munandar, 2021; Novita et al, 2021; Husna, 2020), meningkatkan 
kemampuan guru dalam mengajar (Subarkah et al, 2021; Astuti \& Prestiadi, 2020), meningkatkan kemandirian dan pemahaman materi pembelajaran (Monica \& Fitriawati, 2020).

Uraian di atas menunjukkan bahwa aplikasi (software) pembelajaran daring sangat diperlukan untuk meningkatkan kualitas pembelajaran khususnya di SD Negeri 2 Abiansemal. Oleh karena itu diperlukan suatu penelitian untuk mengukur efektivitas penggunaan aplikasi (software) pembelajaran daring dimasa pandemi Covid-19 pada guru SD Negeri 2 Abiansemal.

\section{Metode}

Jenis penelitian ini adalah eksperimen yang bertujuan untuk mencari pengaruh perlakuan yang diberikan terhadap subjek penelitian (Sugiyono, 2012). Desain yang digunakan pada penelitian ini adalah Pre-Experimental Design dengan model One-Group Pretest-Posttest Design. Penelitian ini dilaksanakan di SD Negeri 2 Abiansemal. Populasi penelitian ini adalah 16 orang guru dan seluruhnya digunakan sebagai sampel. Perlakuan yang diberikan pada penelitian ini berupa pemahaman dan praktik penggunaan google form, zoom, google meet, youtube, quizziz, dan google classroom dalam proses pembelajaran. Instrumen yang digunakan adalah tes model SAMR yang diberikan kepada guru sebelum (pre-test) dan setelah perlakuan (post-test). Analisis data yang digunakan pada penelitian berupa analisis deskriptif kuantitatif untuk mendeskripsikan keadaan data penelitian dan analisis inferensial dengan uji-t berpasangan sebagai uji beda dan N-gain sebagai uji efektivitas.

\begin{tabular}{ccc}
\hline Pre-test & Perlakuan & Post-test \\
$\mathrm{O} 1$ & $\mathrm{X}$ & $\mathrm{O} 2$ \\
\hline
\end{tabular}

Gambar 1. One-Group Pretset-Posttet Design

(Sumber: Sugiyono, 2012)

\section{Hasil dan Pembahasan}

Analisis situasi yang telah dipaparkan sebelumnya menunjukkan bahwa kemampuan guru dalam mengoperasikan software pembelajaran daring belum optimal. Hal ini dibuktikan dengan nilai pretest yang memiliki rentang nilai 50 sampai 75 dengan rata-rata 64,06 dan standar deviasi 7,35. Secara detail, distribusi data pretest dapat dicermati pada tabel 1 .

Tabel 1. Deskripsi Hasil Pretest

\begin{tabular}{cccccc}
\hline No & Perhitungan Interval & X & Interval & f & Kategori \\
\hline 1 & Mean + (1,5 SD) Ke atas & 75 & $75-100$ & 1 & Sangat Baik \\
2 & Mean + (0,5 SD) Ke atas & 58.3 & $58-74$ & 11 & Baik \\
3 & Mean - (0,5 SD) Ke atas & 41.7 & $42-57$ & 4 & Cukup \\
4 & Mean - (1,5 SD) Ke atas & 25 & $25-41$ & 0 & Kurang \\
5 & Mean - (1,5 SD) Ke bawah & 0 & $0-24$ & 0 & Sangat Kurang \\
\hline
\end{tabular}

Hasil pretest sesuai dengan tabel di atas, menunjukkan bahwa hanya $1(6,25 \%)$ guru yang mampu menggunakan software pembelajaran daring dengan sangat baik. Selanjutnya, $11(68,75 \%)$ guru mampu menggunakan software pembelajaran daring dengan baik dan $4(25,00 \%)$ orang guru mampu menggunakan software pembelajaran daring dengan kategori cukup. Hasil ini menunjukkan belum semua guru mampu beradaptasi dengan maksimal untuk memenuhi tuntutan proses pembelajaran pada masa pandemi Covid-19 melalui pemanfaatan beberapa software pembelajaran daring. 
Setelah pelaksanaan perlakuan, guru diberikan tes kembali (posttest) untuk mengukur kemampuan penggunaan software pembelajaran daring. Hasil posttest menunjukkan bahwa nilai yang diperoleh guru memiliki rentang nilai 80 sampai 100, dengan rata-rata 92,19, dan standar deviasi 6,32. Berikut disajikan distribusi data posttest sesuai dengan tabel 2.

Tabel 2. Deskripsi Hasil Posttest

\begin{tabular}{cccccc}
\hline No & Perhitungan Interval & X & Interval & f & Kategori \\
\hline 1 & Mean + (1,5 SD) Ke atas & 75 & $75-100$ & 16 & Sangat Baik \\
2 & Mean + (0,5 SD) Ke atas & 58.3 & $58-74$ & 0 & Baik \\
3 & Mean - (0,5 SD) Ke atas & 41.7 & $42-57$ & 0 & Cukup \\
4 & Mean - (1,5 SD) Ke atas & 25 & $25-41$ & 0 & Kurang \\
5 & Mean - (1,5 SD) Ke bawah & 0 & $0-24$ & 0 & Sangat Kurang \\
\hline
\end{tabular}

Hasil posttest sesuai dengan tabel di atas, menunjukkan bahwa hanya $16(100,00 \%)$ guru yang mampu menggunakan software pembelajaran daring dengan kualifkasi sangat baik. Hasil ini secara deskriptif mampu menunjukkan adanya peningkatan skor yang diperoleh guru. Hal ini diperjelas kembali dengan peningkatan kemampuan guru pada masing-masing level model SAMR pada gambar 2.

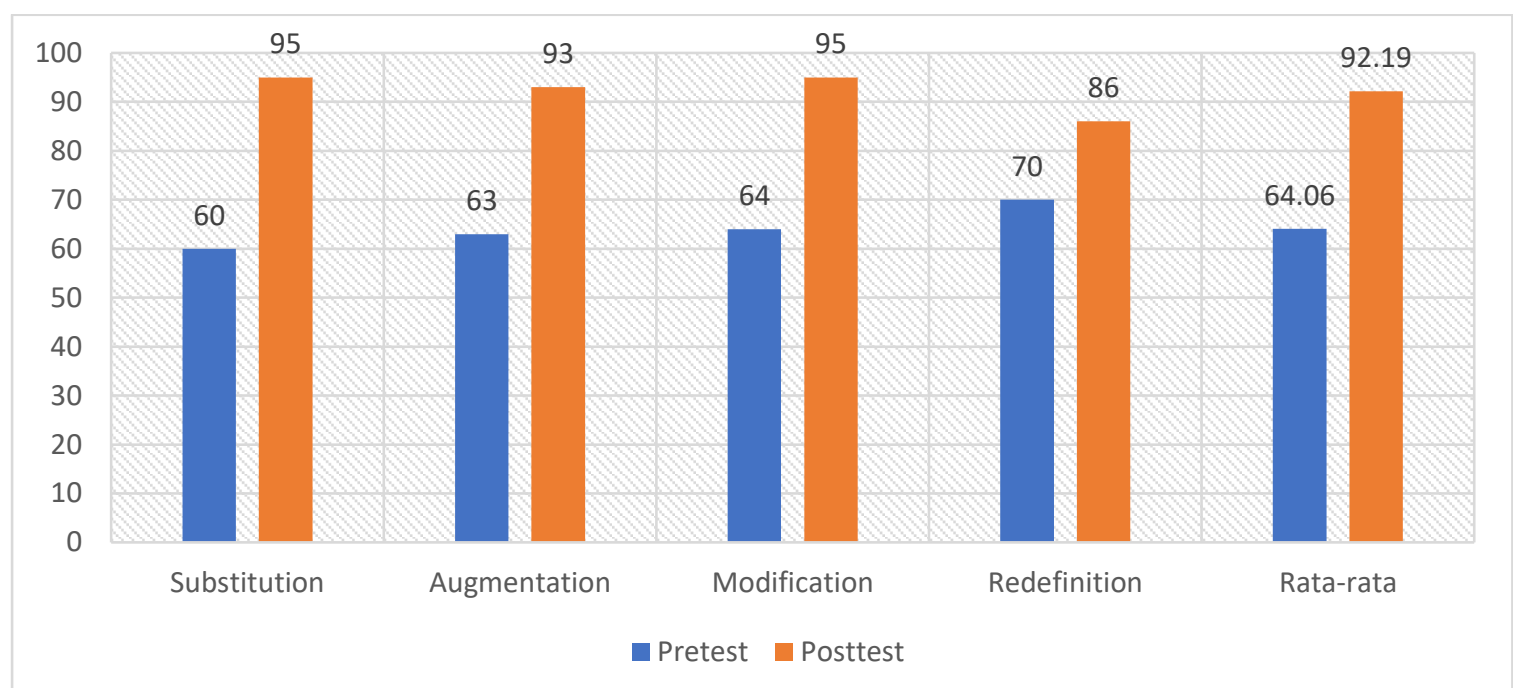

Gambar 2. Perbandingan Nilai Pretest dan Posttest

Selanjutnya, efektivitas penggunaan aplikasi (software) pembelajaran daring dimasa pandemi Covid-19 pada guru SD Negeri 2 Abiansemal dapat dicermati melalui hasil uji-t berpasangan (paired) dan uji efektivitas sebagai berikut:

Tabel 3. Hasil Paired Samples Test

Paired Differences

95\% Confidence

Std. Interval of the

Std. Error Difference Sig. (2-

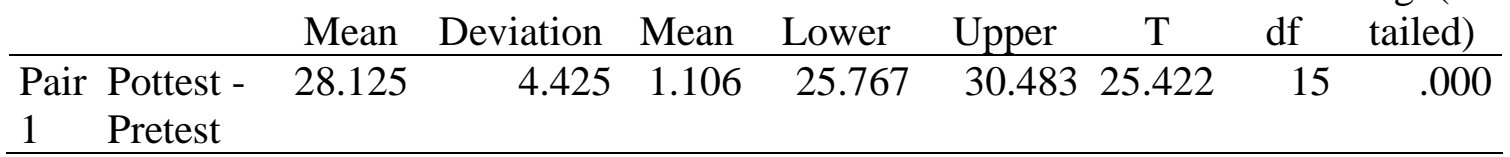


Berdasarkan tabel di atas, signifikansi (2-tailed) hasil uji-t dependent menunjukkan angka 0,000 yang lebih kecil dari 0,05 . Ini berarti, $\mathrm{H}_{\mathrm{o}}$ ditolak atau dengan kata lain terdapat perbedaan hasil pretest dan posttest. Hasil ini juga sesuai dengan uji-t dengan excel yang juga dilaksanakan dengan nilai thitung 25,422. Nilai ini menunjukkan bahwa $t_{\text {hitung }}>t_{\text {tabel, }}$, yaitu 25,422 > 2,131 yang berarti terdapat perbedaan hasil pretest dan posttest. Selanjutnya, hasil uji efektivitas dengan $\mathrm{N}$-gain diperoleh nilai rata-rata $\mathrm{N}$-gain sebesar 0,80 dan presentase N-gain 79,98\%. Sesuai dengan kategori tafsiran efektivitas N-gain, nilai ini berada pada kategori efektif (Hake, 1999). Jadi, penggunaan software pembelajaran daring dimasa pandemi Covid-19 pada guru SD Negeri 2 Abiansemal efektif meningkatkan kemampuan mengajar.

Hasil di atas sesuai dengan penelitian sebelumnya yang menunjukkan bahwa kemampuan guru dalam menggunakan virtual meeting mengalami peningkatan sebesar 24\% selama mengikuti pelatihan (Subarkah et al, 2021). Harapannya, peningkatan kemampuan ini terus diaplikasikan sehingga dapat mendukung kegiatan pembelajaran daring yang dilaksanakan dimasa pandemi Covid-19, karena kemampuan guru menjadi penentu efektivitas pembelajaran daring (Astuti \& Prestiadi, 2020). Selain itu, kompetensi digital dalam penggunaan platform teknologi dan metakognitif merupakan faktor penting untuk mencapai tujuan pembelajaran daring (Joia \& Lorenzo, 2021) sehingga inklusi digital dalam pendidikan diperlukan untuk pengembangan berkelanjutan (Sá \& Serpa, 2020).

Uraian di atas menunjukkan bahwa kemampuan guru dalam menggunakan software untuk mewujudkan pembelajaran daring yang berkualitas merupakan suatu keharusan. Oleh karena itu, perlakuan berupa pemahaman dan praktek penggunaan google form, zoom, google meet, youtube, quizziz, dan google classroom dalam proses pembelajaran kepada guru di SD Negeri 2 Abiansemal merupakan upaya konkret dalam mencapai kualitas pembelajaran yang diinginkan.

Pada saat proses pembelajaran berlangsung, guru dapat menggunakan zoom ataupun google meet untuk berinteraksi secara langsung dengan siswa. Agar proses pembelajaran berjalan lebih interaktif, guru dapat menyajikan media pembelajaran yang relevan melalui youtube kemudian berbagi layar (share screen) kepada siswa sehingga dapat dicermati secara langsung. Atau, boleh juga media pembelajaran yang relevan dapat diunduh terlebih dahulu kemudian ditampilkan saat proses belajar melalui zoom atau google meet.

Pada proses evaluasi pembelajaran, guru dapat menggunakan google form atau quizziz untuk meningkatkan rasa ingin tahu, fokus, dan motivasi belajar siswa. Google form digunakan dalam penilaian sumatif baik penilaian harian, penilaian tengah semester, ataupun penilaian akhir semester. Quizziz digunakan saat pemberian kuis pada akhir proses pembelajaran dan bentuk penilaian formatif lainnya sehingga guru dapat memberikan rewards dan tindak lanjut untuk pembelajaran berikutnya. Selanjutnya, google classroom dapat digunakan sebagai Learning Management System (LMS) sehingga berbagai bentuk materi, media, dan penugasan dalam proses belajar dapat terinventarisir dan dinilai dengan sistematis.

Skema proses belajar, evaluasi, dan manajemen materi pembelajaran sesuai implikasi di atas dapat dilaksanakan secara integratif melalui bentuk model pembelajaran. Salah satu model pembelajaran yang relevan dalam penggunaan software pembelajaran daring adalah blended learning. Model ini mengkombinasikan pembelajaran asynchronous melalui video pada youtube dan pembelajaran synchronous melalui zoom atau google meet. Upaya ini dikenal dengan stratedi DLPCA (Lapitan et al, 2021).

Bentuk lain integrasi skema pembelajaran ini sehingga mewujudkan suasana interaktif dapat dilaksanakan dalam bentuk gamifikasi (Fontana, 2020). Proses pelatihan 
dengan video-game dapat dilaksanakan di rumah dalam bentuk penugasan sebagai persiapan belajar dan dilanjutkan dengan platform konferensi video berupa zoom atau google meet pada kegiatan inti. Upaya ini diharapkan mampu memberikan suasana yang berbeda dan lebih atraktif selama proses pembelajaran.

\section{Kesimpulan}

Sesuai hasil dan pembahasan yang telah dipaparkan sebelumnya dapat disimpulkan bahwa penggunaan software pembelajaran daring dimasa pandemi Covid-19 pada guru SD Negeri 2 Abiansemal efektif meningkatkan kemampuan mengajar. Hal ini dibuktikan dengan rata-rata nilai pretest 64,06 meningkat saat posttest menjadi 92,19 , $t_{\text {hitung }}>t_{\text {tabel }}$, yaitu $25,422>2,131$, dan presentase $\mathrm{N}$-gain 79,98\%. Ini menunjukkan penggunaan software pembelajaran daring harus terus dilatihkan sehingga meningkatkan kemampuan guru dalam memanfaatkan berbagai fitur dalam software untuk menyajikan pembelajaran yang interaktif dan menyenangkan.

Adapun beberapa saran yang dapat diajukan sebagai tindak lanjut dalam penelitian ini, yaitu: (i) pemangku kebijakan diharapkan untuk mengadakan pelatihan guru tentang pembelajaran daring; (i) guru diharapkan dapat memanfaatkan teknologi untuk mencari informasi tentang berbagai bentuk pembelajaran yang interaktif dimasa pandemi Covid19; dan (iii) diharapkan penelitian sejenis dapat dilaksanakan dengan mengontrol faktorfaktor yang mempengaruhi pembelajaran daring dan melaksanakan skema penggunaan software pembelajaran daring dalam bentuk model blended learning atau metode gamifikasi.

\section{Daftar Pustaka}

Astuti, A. D., \& Prestiadi, D. (2020). Efektivitas Penggunaan Media Belajar Dengan Sistem Daring Ditengah Pandemi Covid-19. Prosiding Web-Seminar Nasional (Webinar) Universitas Negeri Malang, 8.

Baety, D. N., \& Munandar, D. R. (2021). Analisis Efektifitas Pembelajaran Daring Dalam Menghadapi Wabah Pandemi Covid-19. EDUKATIF: JURNAL ILMU PENDIDIKAN, 3(3), 880-989. https://doi.org/10.31004/edukatif.v3i3.476

Dias, S. B., Hadjileontiadou, S. J., Diniz, J., \& Hadjileontiadis, L. J. (2020). DeepLMS: A deep learning predictive model for supporting online learning in the Covid-19 era. Scientific Reports, 10(1), 19888. https://doi.org/10.1038/s41598-020-76740-9

Fontana, M. T. (2020). Gamification of ChemDraw during the COVID-19 Pandemic: Investigating How a Serious, Educational-Game Tournament (Molecule Madness) Impacts Student Wellness and Organic Chemistry Skills while Distance Learning. Journal of Chemical Education, 97(9), 3358-3368. https://doi.org/10.1021/acs.jchemed.0c00722

Husna, R. (2020). Efektivitas Pembelajaran Turunan pada Masa Pandemi Covid-19 melalui Media Mobile Learning Ditinjau dari Hasil Belajar Mahasiswa. Jurnal Numeracy, 7(2), 324-333. https://doi.org/10.46244/numeracy.v7i2.1187

Joia, L. A., \& Lorenzo, M. (2021). Zoom In, Zoom Out: The Impact of the COVID-19 Pandemic in the Classroom. Sustainability, 13(5), 2531. https://doi.org/10.3390/su13052531

Lapitan, L. DS., Tiangco, C. E., Sumalinog, D. A. G., Sabarillo, N. S., \& Diaz, J. M. (2021). An effective blended online teaching and learning strategy during the COVID-19 pandemic. Education for Chemical Engineers, 35, 116-131. https://doi.org/10.1016/j.ece.2021.01.012 
Monica, J., \& Fitriawati, D. (2020). Efektivitas Penggunaan Aplikasi Zoom Sebagai Media Pembelajaran Online Pada Mahasiswa Saat Pandemi Covid-19. Jurnal Communio: Jurnal Jurusan Ilmu Komunikasi, 9(2), 1630-1640. https://doi.org/10.35508/jikom.v9i2.2416

Novita, N., Kejora, M. T. B., \& Akil, A. (2021). Efektivitas Penggunaan Aplikasi Zoom Meeting dalam Pembelajaran PAI di Masa Pandemi Covid-19. EDUKATIF: JURNAL ILMU PENDIDIKAN, 3(5), 2961-2969. https://doi.org/10.31004/edukatif.v3i5.1070

Rahmanto, M. A., \& Bunyamin. (2020). Efektivitas Media Pembelajaran Daring melalui Google Classroom. Jurnal Pendidikan Islam, 11(2), 17.

Sá, M. J., \& Serpa, S. (2020). COVID-19 and the Promotion of Digital Competences in Education. Universal Journal of Educational Research, 8(10), 4520-4528. https://doi.org/10.13189/ujer.2020.081020

Subarkah, P., Abdallah, M. M., \& Hidayah, S. O. N. (2021). Pelatihan Penggunaan Virtual Meeting untuk Mendukung Kegiatan Belajar Mengajar bagi Guru. JMM (Jurnal Masyarakat Mandiri), 5(4), 10. https://doi.org/10.31764/jmm.v5i4.4742

Sugiyono. (2012). Metode Penelitian Kuantitatif, Kualitatif, dan Kombinasi (Mixed Methods). Bandung: Alfabeta.

Surat Edaran Menteri Pendidikan dan Kebudayaan Nomor 4 Tahun 2020 tentang Pelaksanaan Kebijakan Pendidikan dalam masa darurat penyebaran Coronavirus Disease (COVID-19). 